\title{
Mathematics Teachers' Pedagogy through Technology: A Systematic Literature Review
}

\author{
Jaafaru Aliyu \\ Department of Mathematics, School of Secondary Edu. Sciences \\ Federal College of Education Zaria, Nigeria \\ https://orcid.org/0000-0002-9124-1445 \\ Sharifah Osman \\ School of Education, Faculty of Social Sciences and Humanities, \\ Universiti Teknologi Malaysia \\ https://orcid.org/0000-0003-2896-9377 \\ Mohd Fadzil Daud \\ School of Mechanical Engineering, Faculty of Engineering, \\ University Teknologi Malaysia \\ https:/ / orcid.org/0000-0001-9046-0649 \\ Jeya Amantha Kumar \\ Centre for Information Technology and Multimedia, \\ University Sains Malaysia \\ https:// orcid.org/0000-0002-6920-0348
}

\begin{abstract}
Mathematics teachers' pedagogy (MTP) is an integral part of classroom instructional mediation through technology or manipulatives. This article describes a logical literature analysis for the MTP and technology with GeoGebra (GG). The findings reveal the intervention impact of MTP with GG and other technologies such as matrix laboratory (MATLAB); an interactive whiteboard (IWB) and computer algebra system (CAS); wxMaxima, which is a CAS; information and communication technologies (ICT); concrete materials as well as other resources in developing students' performances in mathematics which were generally effective too. The systematic literature review (SLR) explored findings from current research between January 2011 and October 2020. Quality assessment screening of the papers was done and alongside further elimination of repeated documents from the analysis, twenty-eight publications met the refinement and inclusion/exclusion criteria out of 110 papers. The modified preferred reporting items for systematic reviews and meta-analyses (PRISMA) outline exemplifies the literature review accordingly. The authors observed, accomplished, and discussed the significance of the SLR. This was followed by the
\end{abstract}


constraints, upcoming directions for MTP with technology and GG, and the MTP consequences for education and research.

Keywords: GeoGebra; Mathematics education; Mathematics teachers' pedagogy; Systematic literature review; Technology

\section{Introduction}

Mathematics is a study of topics such as quantity or numerals, change, shapes, and space. Mathematics tries to find out designs or patterns and use them to convey new conjectures. Thus, it is essential in many fields, such as medicine, natural sciences, engineering, finance, social sciences, and many more. Mathematics has several valuable advantages to our minds if we go into its study. The development of mental thinking/reasoning accelerates our minds and analytical thinking as well as being useful for practical use and day-to-day activities. Usman (2019) stressed that mathematics is the rational language for conveying concepts, structures, capacities, dimensions, other modifications, and vitality in the teaching procedure and clarifying the difficulties of modern society in the professional, commercial, academic, economic and engineering fields for lifelong learning. Without mathematics there is no science, no modern technology, and no national development (Usman, 2019). Furthermore, Chinyere (2016) argues that there is no course of study in our institutions of learning that does not require the knowledge of mathematics; hence its role in science and technology cannot be overemphasised. Mathematics teachers' pedagogy (MTP) in this situation discusses what instructors can do to uphold the best quality practice that may meet the necessary targets of the $21^{\text {st }}$ century. Thus, teachers need to be able to develop strategies on how they can improve effectiveness in their teaching, what scientific training can elevate their levels of competence, and what teachers' content knowledge and what approaches may yield desirable outcomes for students (Warner \& Kaur, 2017).

The TPACK framework proposes that excellent instruction requires a good understanding of the intricate relationships among the three key foundations of information: technology, pedagogy, and content; and reports in what manner they play out in indefinite settings (Mishra et al., 2011). Thus, for successful design in technology integration, schoolteachers must understand more than the technical aspects of technology; they need to comprehend its constraints and benefits both for demonstrating subject matter and distinguishing relevant teaching styles (Mishra et al., 2011). Recently, the TPACK framework has been recommended as an incorporated context for teacher knowledge for successful technology assimilation. Built on Shulman's pedagogical content knowledge (PCK), Mishra et al. (2011) added 'technological' (T), thereby creating TPACK (technological, pedagogical and content knowledge) in 2005. Thus, TPACK is essential for implementing technology and effective instruction. Effective instruction involves teachers' knowing how to operate knowledge and the use of technology in instruction. The TPACK structure comprises three basic components, namely content knowledge (CK), pedagogical knowledge (PK), and technological knowledge (TK) (Luo et al., 2018). 
Furthermore, technology integration (TI) focuses on new knowledge or what can transform modern technology, such as GeoGebra (GG), to have a constructive impact on the students' learning because of the excellence and richness of the lesson materials offered by teachers through the incorporation of technology. Ogbonnaya and Mushipe (2020) stressed that TI, like GG with mathematics training, corresponds to the constructivist philosophy of understanding through knowledge as a dynamic procedure and that society can study via investigation and functioning involvement in the education development. However, in the teaching/learning of mathematics, numerous classroom modification activities are done through designing and developing lesson plans with the aid of supportive innovation that can lead to success in mathematics learning (Za'ba et al., 2020). Thus, what precise abilities and limitations do these tools have and do they bring positive changes to the classroom setting and nurture the progress of students' learning? Accordingly, Za'ba et al. (2020) point out that the achievement of technology integration into teaching/learning transpires when teachers are capable of using technological devices to support them in acquiring information, exploring and incorporating the information, and expressing it proficiently to students. Pfeiffer (2017) argues that many instructors and students have open entry to appropriate software while computers are obtainable both in homes and schools, integrating technology into the daily teaching/learning of mathematics. Also, GG is freely available, and teachers/students can access it through smartphones or computers and can copy it online. Students can even use it in their free time on computers or smartphones (Pfeiffer, 2017). Further, GG or other software through TI can support students' learning activity and challenge the traditional approach of teaching/learning.

Abidin et al. (2019) stressed that a systematic literature review (SLR) is a technique to classify, choose and assess study subject matter appropriate to the research problem. In reviewing a paper, three phases are necessary: preparing the review, performing the review, and informing the review (Abidin et al., 2019). Moreover, there are some challenges associated with SLR that include the need for training, difficulty in synthesising results, formulating the study design, lack of funding, and being time-consuming. Thus, Abidin et al. (2019) argue that the technique in the SLR should comprise setting a question, carrying out a search, recognising the right type of research, and obtaining information from the articles. Subsequently, the conclusions of the review should be brief, and the outline of the assessment should be made known. The information should include the mediation and the pattern result of all the paper evaluations (Abidin et al., 2019).

Consequently, in the PRISMA framework, the existing pieces of evidence are synthesised in the findings. There is always categorisation of the outcomes. SLR has an established protocol for searching strategies and reporting. Duplicate records' removal from the documents is paramount. SLR provides reasons for including or excluding studies and is explicitly informed by the research questions. Data extraction is on current and relevant studies related to the topic of discussion. Finally, included studies only were assessed as to the quality of the review. 
In the findings, the sections are used to explain the entire content of the research in ascending order: Purpose of the Review, Methodology, Results and Discussion (Study of Mathematics Teachers' Pedagogy with Technology, Study of Mathematics Teachers' Pedagogy and GeoGebra and a summary of twentyeight review papers), Limitations, Future Recommendations, Conclusion, Research Implication and References.

\section{Goal of the Review}

The objectives are to map out the existing understanding of the problem. This systematic review (SR) is an integrative and retrospective scientific investigation which intends to answer research questions clearly formulated through a systematic and explicit process. The following research questions were formulated and used to guide the procedure of the SLR, namely (i) What are the findings of the studies in MTP and technology intervention? and (ii) What are the previous studies in MTP and GG intervention?

Based on these research questions, the following objectives were set: (i) to provide an introductory overview of the process; to highlight key standards that can be used to prepare, conduct, and report on SLR; present resources; add values; address the knowledge gap; synthesise multiple studies; and give the best estimate of any true effect. (ii) The study aims to review papers on the effect of MTP using technology and GG as well as offering more descriptions in the field and making recommendations for future development.

In this phase, the planning is according to the PRISMA framework and the questions posed in the research. Thus, the inquiry sequence and the reporting pattern are explained below:

\section{Methodology}

SLR is a technique of sorting and blending result findings that fit precise standards to solve a specific problem (Piper, 2013). It is a process of developing a clear question that utilises logical and specific approaches towards classifying, selecting and crucially assessing or calculating significant investigation, and of collecting and examining the information from the findings for the review. SLR tries to classify, evaluate, and create realistic support that convenes prestipulated appropriateness measures to resolve a provided investigation issue. A meta-evaluation is a statistical review of the information presented from several sources or findings that seeks to enquire or respond to the identical problem (Piper, 2013). Li et al. (2020) argue that performing systematic reviews to investigate the significance of and developments in particular subjects is common in learning research. For instance, investigators analyse the historical progress of study in mathematics education as well as patterns studied with technology used in mathematics education ( $\mathrm{Li}$ et al., 2020).

Consequently, in the current research, a modified PRISMA statement template is used for the methodological procedure to gather, examine, and produce all the related information in the earlier studies to offer the state of the research. Thus, the PRISMA information facilitates the investigator to enrich the coverage of the 
assessment paper (Khan \& Qureshi, 2020) and build on the indicated purposes of the research finding. Figure 1 below shows the literature inclusion and exclusion at every phase:

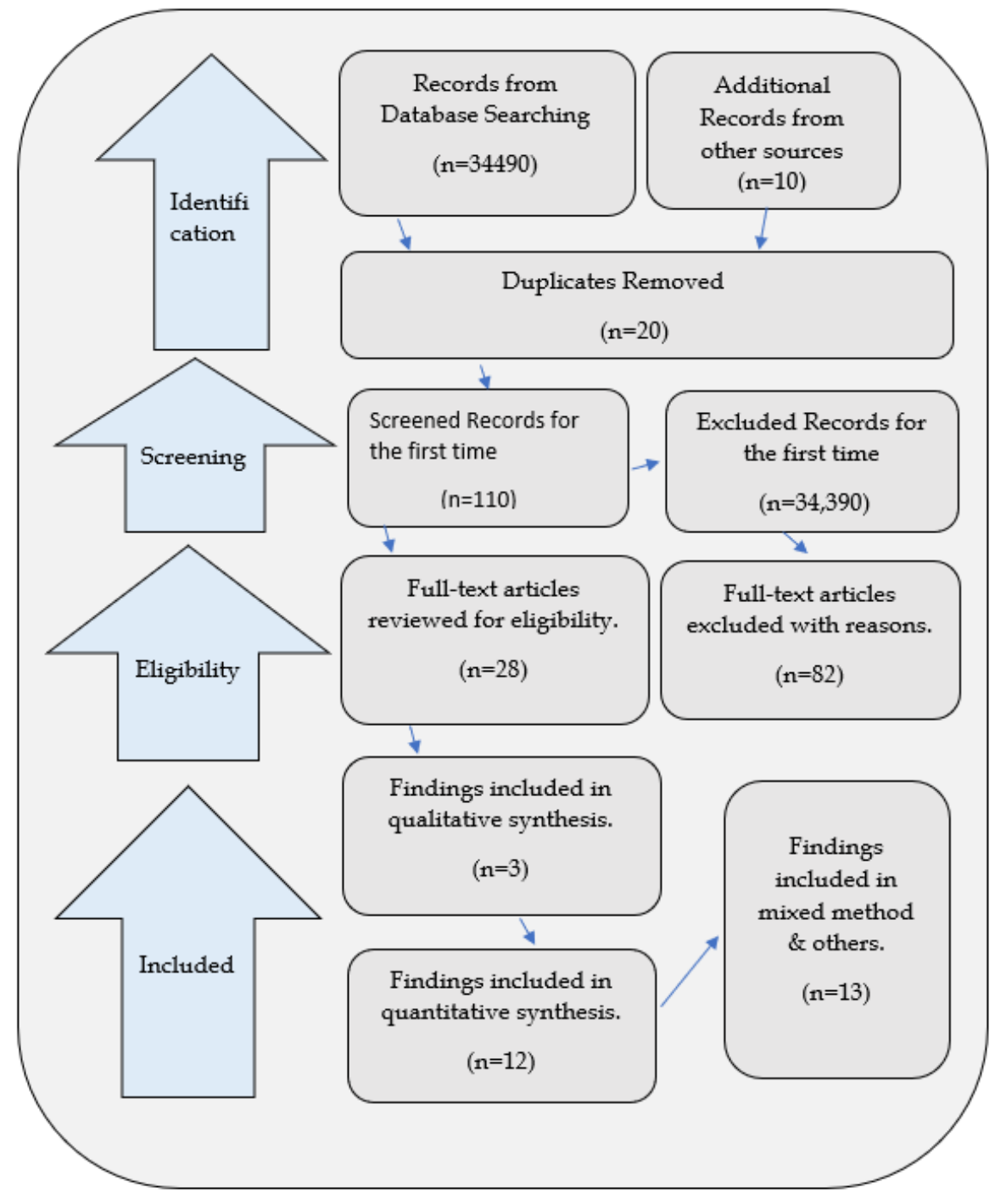

Figure 1: A summary of literature inclusion and exclusion

\subsection{Search Strategies}

For this systematic search, a search strategy was developed to identify relevant literature: Pedagogy OR MTP AND GG OR Technology in Mathematics Education. These search strategies used five databases: IEEE XPLORE, ScienceDirect or Elsevier, Scopus, Springer Link, and Taylor \& Francis Online. In addition, tools such as Google Scholar and Web of Science were used in the belief that they are the leading databases that comprise bibliographic documents with full-text publishing structures in a variety of disciplines and, specifically for educational multidisciplinary research. All searches spanned from databases 0101--2011 until 18-10-2020 and included journals, reviews and conferences published in English only. 


\subsection{Selection Criteria}

The search focused mainly on mapping existing literature on pedagogy (MTP) or with technology (GG) in the field of social sciences. The examination was then restricted to the subject sections, to social sciences, art, and humanity, multidisciplinary and technology with over 34,500 papers. The exploration period was 2011-2020. All articles prior to 2011 were excluded from the examination. The exploration concentrated on all nations globally. Thus, a total 34,390 research articles was excluded at this stage. There were 110 records extracted at this stage.

\subsection{Quality Assessment}

The research is centred on new investigation articles and conference documents. For upholding the integrity of the review, all duplicates were verified comprehensively. The abstracts of the articles were checked meticulously for the evaluation and purification of the articles to certify the excellence and significance of educational information contained in the analysis procedure. A thorough assessment of all inquiry articles was held at a subsequent phase. The following rejection measure was to regulate the documents published in the English language only. There were 10 in other languages and these have been eliminated from the research. Also, refinement of 50 papers was done and these were excluded. Furthermore, after the filtration of duplicate records, 20 more articles were removed from the study. A total of 28 articles were selected after assessing each article on the inclusion and extraction criteria.

\subsection{Data Extraction}

The findings have been limited to conferences, journal articles and review papers from 2011 until 2020 and are accessible in the English Language. A total of 110 papers were found while conducting the review. These papers were examined to detect the objectives of the study. The keywords related to GeoGebra and other technological interventions as used in the previous findings, among others, include the following: (i) GeoGebra assisted students effectively in solving the properties of straight-line graph problems (Mudaly \& Fletcher, 2019). (ii) The outcomes of the post-test indicate that $70-75 \%$ of students answered the questions correctly with the intervention of the GG software (Aizikovitsh-Udi \& Radakovic, 2012). (iii) The statistical assessment demonstrates that the students' knowledge attainment in investigating drawing and graph functions improved with GG (Takači, Stankov, \& Milanovic, 2015). (iv) Nineteen of the candidates enjoyed significant educational success and seven had less success through GG software in the past (İpek et al., 2014). (v) Good practice with technology uses enhanced exploration, inquiry and collaboration among learners (Bray \& Tangney, 2017).

The writers then encapsulated the content into a table for the stage of informing the review. Subsequently, the writers eliminated the papers corresponding to the criteria; 28 papers were found to be reviewed in depth. The review of the results and discussion is presented below. 


\section{Results and Discussion}

Primarily, in the twenty-eight papers evaluated, seventeen conducted the study on secondary/high/college school students, four on primary/elementary school students, and seven on university students. Thus, this information shows that there is a limited amount of research at the primary and university levels. Moreover, only four out of twenty-eight researchers used the TPACK framework in their findings. The researchers incorporated other relevant pedagogies related to technology or ICT as well as information in the instruction and studying of calculation at all levels of education (Costică, 2015). Other writers from the review used a computer algebra system (CAS) that focused on the symbolic manipulation of doing mathematics (Marshall et al., 2012). CAS is a specific kind of mathematical software platform that can control and influence mathematical representations with a conceptual variable quantity. The main goal of a CAS is to systematise monotonous and occasionally challenging algebraic manipulation tasks. Thus, many teachers said that the role of symbolism in classrooms ought to be transformed (Özgün-Koca, 2010).

Currently, in the findings, and also in the previous study, there are various approaches to technology use that include interactive whiteboard (IWB) (Ayub et al., 2012), MATLAB (Beauchamp \& Kennewell, 2013), and wxMAXIMA (Costică, 2015). Most of the papers reported the use of pedagogy or technology or mathematics software for intervention purposes. The roles of these tools in the education and understanding of mathematics bring changes to pupils' learning and encourage an increase of students' discoveries (Yong et al., 2019). Moreover, it enables students to gain access to a variety of unusual solution sets, and to experiment and construct with geometrical tools to make assumptions and clarifications. Graphics or visuals facilitate knowledge access and improve students' attitude to the issues of a subject traditionally regarded as being difficult (Ayub et al., 2012; Beauchamp \& Kennewell, 2013; Costică, 2015).

However, in the elementary-school mathematics classroom, it is necessary for the use of augmented reality to adopt the curriculum subject (Radu et al., 2016). Computer-assisted instruction (CAI) has a significant effect on the teaching/learning of mathematics (Young, 2017). Thus, good practice through technology-enhanced exploration, inquiry and collaboration is required (Bray \& Tangney, 2017). 
Table 1: Study of mathematics teachers' pedagogy with technology

Citation Instrument MTP \&Technology $\quad$ Results

Lye, 2013 TPACK; education technology; ICT in education

Kaarakka et MathCheck; pedagogy; al., 2019

AlAbdullatif \& Alsaeed, 2019

Young, Calculators; meta-evaluation; 2017

Kalloo, Mohan, \& Kinshuk, 2016

Yong et al., 2019

Zualkernan , 2015

Radu et al 2016

Kurvinen et Teacher feedback: technologyal., 2019 enhanced learning

Bray \& Tangney, 2017 classroom instruction; teachers' augmented reality; prototyping; mathematics

Visible learning ICT integration; mathematics classrooms; technology-enhanced (TI) Technology; computer-assisted instruction; mathematics achievement

\section{Learning game design} pedagogy; competition design; mathematics games; major games; event model lenses

\section{Digital event-centred learning;} educational games; COTS; mathematics; tutors, parents, and undergraduates

Gender-variations; growing countries; online-learning; equipment-enhanced learning; mathematics

Technology-enhanced learning; mathematics education; secondary education, SLR
MathCheck encouragement

Around Saudi Arabia, there is a need for re-evaluating their instructors' outcomes on learner's knowledge through TI

Statistically important moderator of the effects on mathematics through technology enhancement

In studying sport design there is a need for the insertion of pedagogical concepts into the new requirement.

Students should explore Digital Game-Based Learning (DGBL) on their own

With or without the use of technology, as observed there is no considerable disparity in performance among female and male children for class II and class V proficiency

In the elementary-school math classroom, there are few opportunities for adopting the curriculum subjects

The programme constructed and executed at the University of Turku called Ville to improve teachers' confidence

Excellent preparation with technology uses improved inquiry, exploration, and co-operation, whereby the teacher functions as a mediator of knowledge 


\begin{tabular}{|c|c|c|}
\hline $\begin{array}{l}\text { Akkaya, } \\
2016\end{array}$ & $\begin{array}{l}\text { Mathematics instruction; } \\
\text { intermediate school } \\
\text { mathematics pre-service } \\
\text { instructors; technology (TPCK) }\end{array}$ & $\begin{array}{l}\text { Pre-service tutors to have guidance } \\
\text { on TPACK and re-evaluated in the } \\
\text { context of TPACK to primary } \\
\text { mathematics tutors }\end{array}$ \\
\hline $\begin{array}{l}\text { Beauchamp } \\
\& \\
\text { Kennewell, } \\
2013\end{array}$ & $\begin{array}{l}\text { IWB; transition; } \\
\text { instrumentation; affordance; } \\
\text { instructor's role; tutor learning }\end{array}$ & $\begin{array}{l}\text { A knowledgeable instructor and } \\
\text { learners can devise the IWB system } \\
\text { to accelerate successful learning by } \\
\text { the students }\end{array}$ \\
\hline $\begin{array}{l}\text { Saralar, } \\
\text { Işiksal- } \\
\text { Bostan, \& } \\
\text { Akyüz, } \\
2018\end{array}$ & $\begin{array}{l}\text { Collaborative learning; } \\
\text { constructivism; mathematics; } \\
\text { function; problem-solving }\end{array}$ & $\begin{array}{l}\text { Delivers results on TPACK. The pre- } \\
\text { service teachers use dynamic } \\
\text { geometry as observed through their } \\
\text { planning artefacts and evaluation } \\
\text { with TPACK structure }\end{array}$ \\
\hline $\begin{array}{l}\text { McCulloch } \\
\text { et al., } 2018\end{array}$ & $\begin{array}{l}\text { Enhancing teaching; pedagogical } \\
\text { issues; learning/teaching plans; } \\
\text { secondary education }\end{array}$ & $\begin{array}{l}\text { Teachers should gain access to a } \\
\text { range of various technology } \\
\text { instruments and be prepared to use } \\
\text { the knowledge they need at their } \\
\text { college }\end{array}$ \\
\hline $\begin{array}{l}\text { Chen \& } \\
\text { Jang, } 2014\end{array}$ & $\begin{array}{l}\text { Stages of concern; TPACK; TI; } \\
\text { career development; Taiwan }\end{array}$ & $\begin{array}{l}\text { Investigate the interrelatedness } \\
\text { among instructor concerns and their } \\
\text { learning formation (TPACK) }\end{array}$ \\
\hline $\begin{array}{l}\text { Bano et al., } \\
2018\end{array}$ & $\begin{array}{l}\text { Science education; mathematics } \\
\text { education; pedagogy; mobile } \\
\text { learning }\end{array}$ & $\begin{array}{l}\text { Examining the relationship between } \\
\text { mobile learning and these } \\
\text { pedagogies through SLR }\end{array}$ \\
\hline $\begin{array}{l}\text { da Silva } \\
\text { Figueira- } \\
\text { Sampaio et } \\
\text { al., } 2013\end{array}$ & $\begin{array}{l}\text { Mathematics; K-12 schools; solid } \\
\text { materials; coaching systems }\end{array}$ & $\begin{array}{l}\text { Schoolteachers use tangible } \\
\text { resources for teaching mathematics } \\
\text { and materials are valuable and } \\
\text { attractive }\end{array}$ \\
\hline $\begin{array}{l}\text { Backfisch } \\
\text { et al., } 2020\end{array}$ & $\begin{array}{l}\text { Learning technology; capability } \\
\text { research; specialised knowledge; } \\
\text { anticipation-value theory; } \\
\text { teaching mathematics }\end{array}$ & $\begin{array}{l}\text { Motivational values with } \\
\text { instructors' role for learning } \\
\text { technologies perform a vital status } \\
\text { in incorporating technology into } \\
\text { mathematics instruction }\end{array}$ \\
\hline $\begin{array}{l}\text { Kivkovich, } \\
2015\end{array}$ & $\begin{array}{l}\text { Teaching strategies; geometry; } \\
\text { mediation; mathematics; pupils' } \\
\text { attitudes }\end{array}$ & $\begin{array}{l}\text { Teachers can utilise tools for } \\
\text { comprehensive and feature } \\
\text { intermediated learning by dialogic } \\
\text { communication. These include } \\
\text { spoken and non-verbal aspects }\end{array}$ \\
\hline $\begin{array}{l}\text { Marshall et } \\
\text { al., } 2012\end{array}$ & $\begin{array}{l}\text { Post-secondary education } \\
\text { applications in subject areas; } \\
\text { improving classroom teaching; } \\
\text { human-computer interface }\end{array}$ & $\begin{array}{l}\text { Using CAS largely to have students' } \\
\text { discover and imagine mathematical } \\
\text { notions }\end{array}$ \\
\hline
\end{tabular}




\begin{tabular}{lll}
\hline $\begin{array}{l}\text { Ayub et al., } \\
2012\end{array}$ & $\begin{array}{l}\text { Great approach; calculus; } \\
\text { wxMaxima; surface approach; } \\
\text { CAI }\end{array}$ & $\begin{array}{l}\text { wxMaxima as a teaching aid may } \\
\text { develop mathematics at the } \\
\text { Malaysia secondary school stage }\end{array}$ \\
$\begin{array}{ll}\text { Costică, } \\
2015\end{array}$ & $\begin{array}{l}\text { Computing technology; the } \\
\text { geometric representations. } \\
\text { competition; tetrahedron; } \\
\text { parallelepiped }\end{array}$ & $\begin{array}{l}\text { Creates cognition, develops a } \\
\text { suitable behaviour, and uses } \\
\text { pedagogical practice, the AEL lesson } \\
\text { packs and special software such as }\end{array}$ \\
& GG, MATLAB, and Maple \\
\hline
\end{tabular}

Re-examining teachers' effect on learners' skill and development through technology (Al-Abdullatif \& Alsaeed, 2019), inserting pedagogical theories into learning game design and exploring digital game-based learning (DGBL) are paramount (Kalloo et al., 2016). Thus, the design and implementation of a platform such as Ville (Kurvinen et al., 2019) and feedback in the use of MathCheck improve teachers' confidence, provide encouragement and offer opportunities for adopting the curriculum subjects in schools (Kaarakka et al., 2019).

Training through TPACK for primary mathematics teachers may improve best practices (Akkaya, 2016). Evaluating the TPACK of pre-service teachers using a dynamic geometry environment can enhance learning (Akkaya, 2016). Assessing the interrelationship among educator concerns and their familiarity formation (TPACK) found that, out of 26 participants, 19 have high levels of academic success (Chen \& Jang, 2014).

Similarly, the role of teachers in orchestrating the IWB environment to simplify efficient learning by the students, software such as GG, MATLAB and Maple, creates cognition to the learners, using CAS to visualise and explore mathematical concepts and wxMaxima could serve as useful teaching aids (Ayub et al., 2012; Beauchamp \& Kennewell, 2013; Costică, 2015).

Moreover, teachers use concrete materials for teaching mathematics, which is useful and attractive for teachers to use tools for complete and quality mediated learning (Da Silva Figueira-Sampaio et al., 2013). Motivational beliefs and teachers' role are key factors in adding technology into mathematics instruction (Backfisch et al., 2020). Besides, it is paramount that teachers have to get and use different technology instruments at their school (McCulloch et al., 2018). Zualkernan (2015) stressed that, in the developing countries, in technologyenhanced leaning of mathematics, with or without the e-learning, there is no substantial difference in implementation between male and female children for grade II and grade V numeracy (Zualkernan, 2015).

Consequently, technology enhancement moderates effects on mathematics, Good practice with technology uses enhanced exploration, inquiry and collaboration as well as examining the relationship between mobile learning and pedagogies (Bano et al., 2018). 
Table 2: Study of mathematics teachers' pedagogy and GeoGebra

\begin{tabular}{|c|c|c|}
\hline Citation & Instrument (MTP)\&GG & Results \\
\hline $\begin{array}{l}\text { Khoza \& } \\
\text { Biyela, } 2019\end{array}$ & $\begin{array}{l}\text { Content; GG; knowledge; } \\
\text { mathematics; pedagogy; } \\
\text { technology }\end{array}$ & $\begin{array}{l}\text { The solution to the decolonisation } \\
\text { of education can be done using } \\
\text { pedagogical information to } \\
\text { generate a realistic curriculum }\end{array}$ \\
\hline $\begin{array}{l}\text { Mudaly \& } \\
\text { Fletcher, } \\
2019\end{array}$ & $\begin{array}{l}\text { iPad technology; mathematics } \\
\text { teaching; linear functions; GG } \\
\text { software manipulation }\end{array}$ & $\begin{array}{l}\text { A positive outlook by participants } \\
\text { towards the use of the GG app in } \\
\text { collaborative learning }\end{array}$ \\
\hline Aliyev, 2011 & $\begin{array}{l}\text { Using ICT in teaching } \\
\text { geometry in mathematics } \\
\text { classroom }\end{array}$ & $\begin{array}{l}\text { The existence of four and three-way } \\
\text { relationship inscribed to one and } \\
\text { constrained about other triangles } \\
\text { and Apollonius (red) circle and its } \\
\text { generating blue tangent circles are } \\
\text { developed }\end{array}$ \\
\hline $\begin{array}{l}\text { Aizikovitsh- } \\
\text { Udi \& } \\
\text { Radakovic, } \\
2012\end{array}$ & $\begin{array}{l}\text { GG; high order thinking; } \\
\text { critical thinking; Bayes' } \\
\text { theorem }\end{array}$ & $\begin{array}{l}\text { The marks of the post-test illustrate } \\
\text { that } 70 \%-75 \% \text { of students were able } \\
\text { to solve the questions correctly } \\
\text { with the help of the software. } \\
\text { The statistical analysis proves that }\end{array}$ \\
\hline $\begin{array}{l}\text { Takači, } \\
\text { Stankov, \& } \\
\text { Milanovic, } \\
2015\end{array}$ & $\begin{array}{l}\text { Collaborative learning; } \\
\text { constructivism; mathematics; } \\
\text { function; problem solving }\end{array}$ & $\begin{array}{l}\text { the students' learning achievement } \\
\text { in examining functions and } \\
\text { drawing their graphs is better when } \\
\text { they use GG }\end{array}$ \\
\hline $\begin{array}{l}\text { İpek et al., } \\
2014\end{array}$ & $\begin{array}{l}\text { Mathematics instruction; } \\
\text { geometry education; CAS; } \\
\text { computer-assisted geometry } \\
\text { education; TPACK; GG }\end{array}$ & $\begin{array}{l}\text { Nineteen participants have high } \\
\text { academic success while seven have } \\
\text { less and only one contributor had } \\
\text { previously heard about GG } \\
\text { software }\end{array}$ \\
\hline
\end{tabular}

Therefore, GG is user-friendly and free software that promotes high-order thinking. Critical thinking may help students to solve the questions correctly with the help of the software, it encourages collaborative learning, construction of knowledge, problem solving, and helps students' learning achievement (Misrom et al., 2020; Mudaly \& Fletcher, 2019) in examining functions and drawing a better graph with the use of GG as well as in TPACK (Takači et al., 2015) and mathematics instruction with CAS (İpek et al., 2014).

Moreover, the software can be used in teaching linear functions in a collaborative learning environment with a positive outcome from the students. Thus, it generates a realistic curriculum from the solution to the decolonisation of education (Khoza \& Biyela, 2019). Besides, the content knowledge of mathematics pedagogy, and the use of ICT in the teaching of geometry in the mathematics classroom and specifically in solving four triangles inscribed to one and circumscribed about other triangles and Apollonius (red) circle and its generating tangent (blue) circles are achieved (Aliyev, 2011).

In this assessment, numerous sources from conferences peer-reviews and journals that support the findings are included. There were twelve quantitative, 
three qualitative, six mixed-method, three review and five empirical studies that investigated the pedagogy or MTP with GG. A summary of the reviewed articles is illustrated in Table 3 below:

Table 3: An outline of the 28 reviewed studies

\begin{tabular}{|c|c|c|c|}
\hline Researcher \& year & Country & Research type & Method \\
\hline $\begin{array}{l}\text { Aizikovitsh-Udi \& } \\
\text { Radakovic (2012) }\end{array}$ & Israel & $\begin{array}{l}\text { Social and Behavioural } \\
\text { Sciences }\end{array}$ & Quantitative \\
\hline $\begin{array}{l}\text { Akkaya (2016) } \\
\text { Al-Abdullatif \& } \\
\text { Alsaeed (2019) }\end{array}$ & $\begin{array}{l}\text { Turkey } \\
\text { Saudi }\end{array}$ & $\begin{array}{l}\text { Eurasia Journal of MSTE } \\
\text { Cogent Education }\end{array}$ & $\begin{array}{l}\text { Mixed method } \\
\text { Quantitative }\end{array}$ \\
\hline Aliyev (2011) & Azerbaijan & Inter Conference on ICT & Empirical \\
\hline Ayub et al. (2012) & Malaysia & $\begin{array}{l}\text { Social and Behavioural } \\
\text { Sciences }\end{array}$ & Quantitative \\
\hline Backfisch et al. (2020) & Germany & Learning and Instruction & Quantitative \\
\hline Bano et al.(2018) & Australia & Computers \& Education & SLR \\
\hline $\begin{array}{l}\text { Beauchamp \& } \\
\text { Kennewell (2013) }\end{array}$ & UK & Educ Inf Technology & Empirical \\
\hline $\begin{array}{l}\text { Bray \& Tangney } \\
\text { (2017) }\end{array}$ & Ireland & Computers \& Education & SLR \\
\hline Chen \& Jang (2014) & Taiwan & $\begin{array}{l}\text { Computers in Human } \\
\text { Behaviour }\end{array}$ & Quantitative \\
\hline Costica, (2015) & Romania & $\begin{array}{l}\text { Social and Behavioural } \\
\text { Sciences }\end{array}$ & Quantitative \\
\hline $\begin{array}{l}\text { Figueira-Sampaio et } \\
\text { al. (2013) }\end{array}$ & Brazil & $\begin{array}{l}\text { Social and Behavioural } \\
\text { Sciences }\end{array}$ & Quantitative \\
\hline İpek et al.(2014) & Turkey & $\begin{array}{l}\text { Social and Behavioural } \\
\text { Sciences }\end{array}$ & Mixed method \\
\hline Kaarakka et al. (2019) & Finland & LUMAT & Quantitative \\
\hline Kalloo et al. (2016) & $\begin{array}{l}\text { Trinidad } \\
\text { Tobago }\end{array}$ & Inter Conference on ALT & Empirical \\
\hline Khoza \& Biyela (2019 & $\begin{array}{l}\text { South } \\
\text { African }\end{array}$ & $\begin{array}{l}\text { Education and Info } \\
\text { Technologies }\end{array}$ & Mixed method \\
\hline Kivkovich (2015) & Romania & $\begin{array}{l}\text { Social and Behavioural } \\
\text { Sciences }\end{array}$ & Mixed method \\
\hline Kurvinen et al. (2019) & Finland & MIPRO, IEEE & Mixed method \\
\hline Lye (2013) & Malaysia & $\begin{array}{l}\text { Social and Behavioural } \\
\text { Sciences }\end{array}$ & Mixed method \\
\hline Marshall et al. (2012) & Canada & Computers \& Education & Quantitative \\
\hline $\begin{array}{l}\text { McCulloch et al. } \\
\text { (2018) }\end{array}$ & USA & Computers \& Education & Qualitative \\
\hline $\begin{array}{l}\text { Mudaly\& Fletcher } \\
\text { (2019) }\end{array}$ & $\begin{array}{l}\text { South } \\
\text { Africa }\end{array}$ & $\begin{array}{l}\text { Prob of Educ in the } 21^{\text {st }} \\
\text { Century }\end{array}$ & Qualitative \\
\hline Radu et al. (2016) & Georgia & IEEE Virtual Reality & Empirical \\
\hline Saralar et al. (2018) & Turkey & $\begin{array}{l}\text { International Journal for } \\
\text { TME }\end{array}$ & Qualitative \\
\hline Takaci et al. (2015) & Serbia & Computers \& Education & Mixed method \\
\hline Yong et al (2019) & Malaysia & Peer-review IEEE & Quantitative \\
\hline Young (2017) & USA & $\begin{array}{l}\text { Educational Research } \\
\text { Journal }\end{array}$ & Review \\
\hline Zualkernan (2015) & UAE & IEEE GHTC & Quantitative \\
\hline
\end{tabular}




\section{Limitations}

The nominated investigations cover an array of nations. Thus, in this research, there are a limited number of research studies in primary schools (3) and universities (8) as compared to high/secondary schools (17). Several studies were performed in one or more frameworks (Daoud et al., 2020) and others were done in the same situation, but adopted different learning principles (Daoud et al., 2020). Figure 2 summarises the scenario by country/territory:

\section{Documents by country or territory}

Compare the document counts for up to 15 countries/territories



Figure 2: Documents by country or territory

The USA, Canada, Spain, the UK, and Sweden remained the most studied individual countries and in one database South Africa met the inclusion criteria. Thus, there were no findings that coincided with the inclusion provisions from Africa according to some data bases used. Figure 3 below indicates documents by citations. 


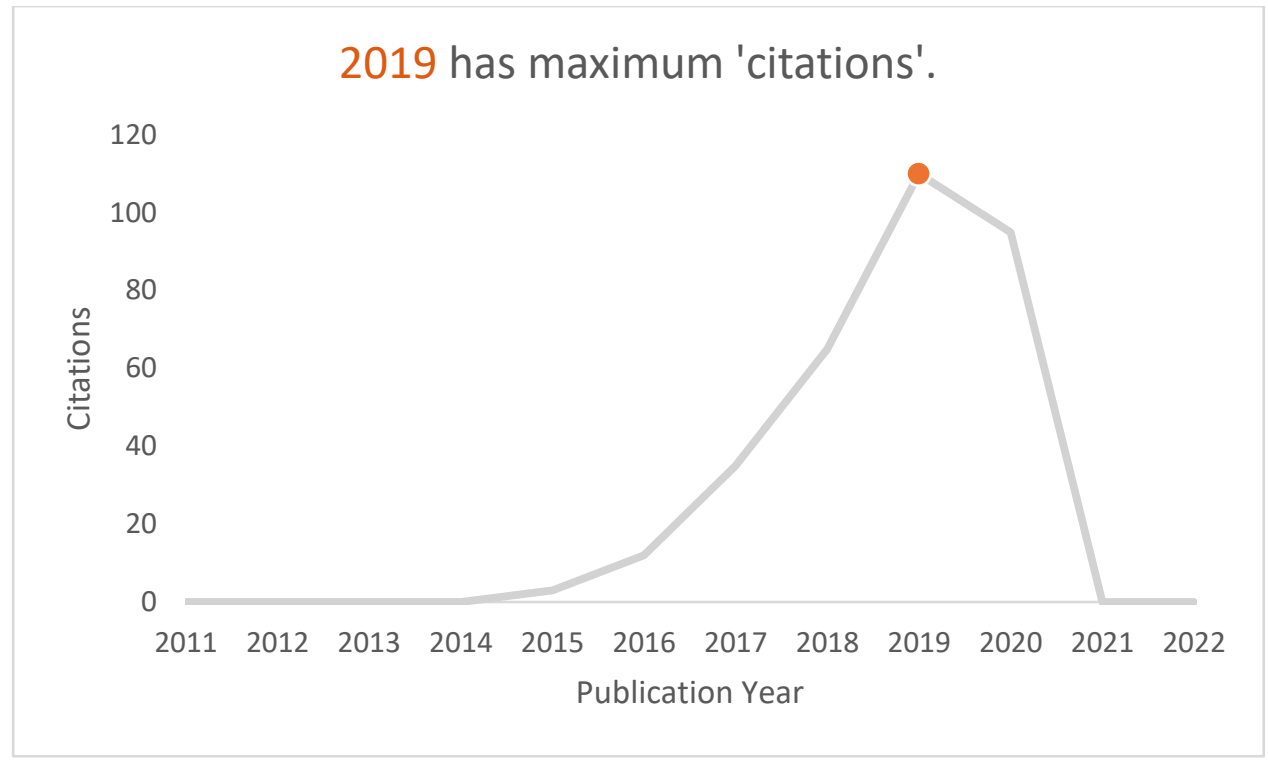

Figure 3: Documents by citations

Consequently, the articles within the review identified and reported information on the aspects of documents by citation, subject area, and by year. Mathematics has only $5.1 \%$ while social sciences had $51.9 \%$. This indicates the need for more article writers in the field of mathematics as illustrated in Figure 4 below:

Documents by subject area



Figure 4: Documents by subject area 
Documents by year

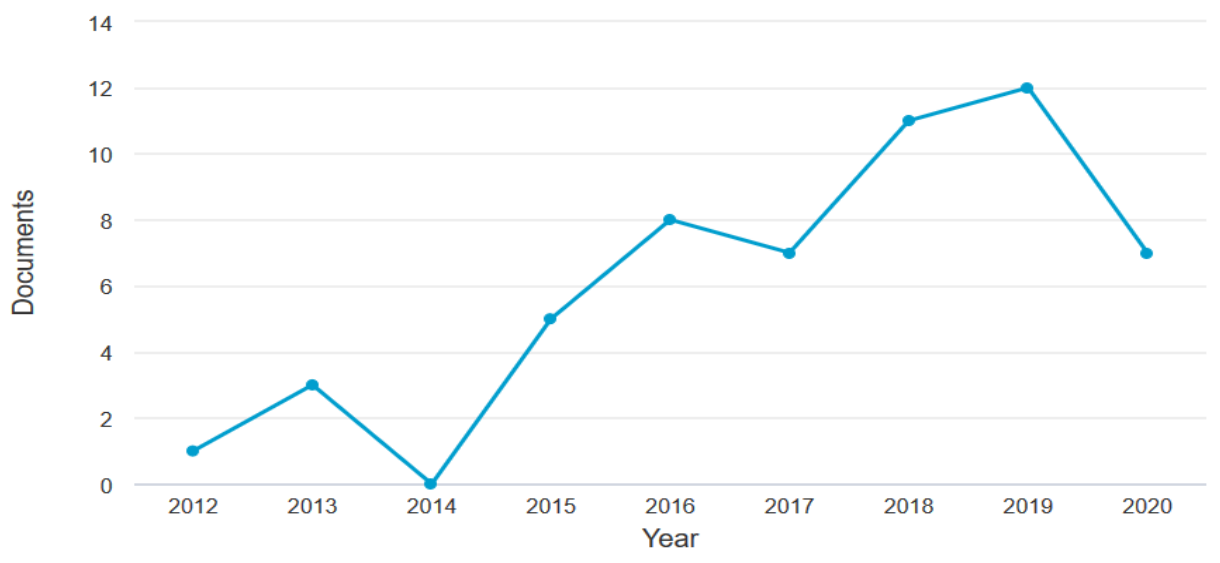

Figure 5: Documents by year

Moreover, documents by year indicate 2011 no records, 2012 only 1, 2014 no documents, 2015 with five papers, 2016 with eight papers, 2019 with the highest of twelve articles, and 2020 with seven publications. Thus, this information reveals that there are generally few writers per year in this field of studies.

\section{Future Recommendations}

The current systematic review reveals that the research studies conducted in the area of MTP and GG focus on instructional materials that include MATLAB, IWB, wxMaxima and others with specification on primary, high schools/colleges, and universities through technology intervention and manipulatives.

Consequently, attention to other learning areas such as Solving $3 \times 3$ simultaneous equations with GG, complex numbers, and algebraic proofs are paramount. The use of alternative strategies such as TPACK and GG could develop the quality and discovery in MTP.

\section{Conclusion}

This review aimed to evaluate the MTP through TI. A modified PRISMA framework (data extraction, quality assessment, selection criteria, and search strategies) was used to demonstrate the entire scenario in the literature review, and 28 out of 110 papers met the criteria. Data extraction was restricted to journals, review papers and conferences in English language only from previous studies. Results of the discussion outcome related to MTP with technology and MTP with GG showed a positive outcome. The summary of the reviewed articles illustrated justification of the research methodology assessment findings. Thus, the objectives of the review, some limitations and future direction were discussed. The use of various interventions, such as an interactive whiteboard (IWB), the dynamic geometry software (DGS), the CAS, GG and other pedagogies shape and promote the learning of mathematics. Moreover, most of the writers focus on secondary schools and colleges with few on primary schools and universities. Hence, documents by country, citations, subject area, and by 
year indicate areas of weakness and that there are limited researches on those areas of study. Thus, potential suggestions were made with respect to GG and MTP.

\section{Research Implications}

The implication of MTP to educational practice and research is dynamic and significant to the learners' logical thinking ability and may foster a good understanding of content knowledge. MTP is a catalyst that sustains best practice through critical thinking, technology, communication, and confidence. Pedagogy is a vibrant and flexible phenomenon that promotes awareness and gives support to students. The MTP is a stimulus for the development and evaluation of teacher preparation programmes. Also, MTP enhances teamwork and interest for the students to learn as peers and alleviate learning obstacles. Multiple representations in MTP through technology (GG) help in addressing students' learning misconceptions. Encouragement for MTP in the teaching processes may nurture the attainment of a well-established knowledge base. Research into MTP demonstrates the shift and assimilation of knowledge, both in theory and practice, and needs to be further investigated and conducted.

\section{Acknowledgment}

This work was supported by the Contract Research Grant (R.J130000.7651.4C430).

\section{References}

Abidin, M., Ismail, Z., \& Ismail, N. (2019, November 8-9). Geometrical thinking with technology: A systematic literature review. In Proceedings of the 2018 IEEE 10th International Conference on Engineering Education, ICEED, pp. 230-235. Kuala Lumpa, Malaysia. https://doi.org/10.1109/ICEED.2018.8626949

Aizikovitsh-Udi, E., \& Radakovic, N. (2012). Teaching probability by using GeoGebra dynamic tool and implemanting critical thinking skills. Procedia - Social and Behavioral Sciences, 46, 4943-4947. https://doi.org/10.1016/j.sbspro.2012.06.364

Akkaya, R. (2016). Research on the development of middle school mathematics preservice teachers' perceptions regarding the use of technology in teaching mathematics. Eurasia Journal of Mathematics, Science and Technology Education, 12(4), 861-879. https:// doi.org/10.12973/eurasia.2016.1257a

Al-Abdullatif, A. M., \& Alsaeed, M. S. (2019). Evaluating visible learning: Mathematics teachers' practices in technology-enhanced classrooms. Cogent Education, 6(1), 124. https:// doi.org/10.1080/2331186X.2019.1686798

Aliyev, Y. N. (2011, October 12-14). Use of dynamic geometry software in teaching and research. In Proceedings of the 2011 5th International Conference on Application of Information and Communication Technologies, AICT, pp. 7-9. Azerbaijan, Baku. https://doi.org/10.1109/ICAICT.2011.6110920

Ayub, A. F. M., Tarmizi, R. A., Bakar, K. A., \& Luan Wong, S. (2012). WxMaxima computer software as an aid to the study of calculus by students with different learning approaches. Procedia - Social and Behavioral Sciences, 64, 467-473. https://doi.org/10.1016/j.sbspro.2012.11.055

Backfisch, I., Lachner, A., Hische, C., Loose, F., \& Scheiter, K. (2020). Professional knowledge or motivation? Investigating the role of teachers' expertise on the quality of technology-enhanced lesson plans. Learning and Instruction, 66(March 2019), 101300. https://doi.org/10.1016/j.learninstruc.2019.101300 
Bano, M., Zowghi, D., Kearney, M., Schuck, S., \& Aubusson, P. (2018). Mobile learning for science and mathematics school education: A systematic review of empirical evidence. Computers and Education, 121(February), 30-58. https:// doi.org/10.1016/j.compedu.2018.02.006

Beauchamp, G., \& Kennewell, S. (2013). Transition in pedagogical orchestration using the interactive whiteboard. Education and Information Technologies, 18(2), 179-191. https:// doi.org/10.1007/s10639-012-9230-z

Bray, A., \& Tangney, B. (2017). Technology usage in mathematics education research - A systematic review of recent trends. Computers and Education, 114, 255-273. https:// doi.org/10.1016/j.compedu.2017.07.004

Chen, Y. H., \& Jang, S. J. (2014). Interrelationship between stages of concern and technological, pedagogical, and content knowledge: A study on Taiwanese senior high school in-service teachers. Computers in Human Behavior, 32, 79-91. https://doi.org/10.1016/j.chb.2013.11.011

Chinyere, C. O. (2016). Effects of constructivist instructional approach on senior secondary school students' achievement and interest in mathematics [Thesis]. University of Nigeria.

Costică, L. (2015). Methods of demonstrating the collinearity of points in space. Procedia Social and Behavioral Sciences, 180, 847-853. https://doi.org/10.1016/j.sbspro.2015.02.223

Da Silva Figueira-Sampaio, A., Dos Santos, E. E. F. Carrijo, G. A., \& Cardoso, A. (2013). Survey of mathematics practices with concrete materials used in Brazilian schools. Procedia - Social and Behavioral Sciences, 93, 151-157. https://doi.org/10.1016/j.sbspro.2013.09.169

Daoud, R., Starkey, L., Eppel, E., Vo, T. D., \& Sylvester, A. (2020). The educational value of internet use in the home for school children: A systematic review of literature. Journal of Research on Technology in Education, 1-22. https://doi.org/10.1080/15391523.2020.1783402

İpek, J., Karasu, M., Kayahan, S., Çukurbaşi, E., \& Yeşil, E. (2014a). Inspection of technopedagogical educational qualifications of mathematics teacher candidates. Procedia - Social and Behavioral Sciences, 141, 718-725. https://doi.org/10.1016/j.sbspro.2014.05.126

Kaarakka, T., Helkala, K., Valmari, A., \& Joutsenlahti, M. (2019). Pedagogical experiments with MathCheck in university teaching. Lumat, 7(3), 84-112. https://doi.org/10.31129/LUMAT.7.3.428

Kalloo, V., Mohan, P., \& Kinshuk. (2016). An investigative process for enhancing the design of a mathematics learning game. In Proceedings - IEEE 16th International Conference on Advanced Learning Technologies, ICALT, Austin, TX, USA, 2016 pp. 117-119. https:// doi.org/10.1109/ICALT.2016.20

Khan, N., \& Qureshi, M. I. (2020). A systematic literature review on online medical services in Malaysia. International Journal of Online and Biomedical Engineering, 16(6), 107-118. https://doi.org/10.3991/ijoe.v16i06.13573

Khoza, S. B., \& Biyela, A. T. (2019). Decolonising technological pedagogical content knowledge of first year mathematics students. Education and Information Technologies, 25(4), 2665-2679. https://doi.org/10.1007/s10639-019-10084-4

Kivkovich, N. (2015). A tool for solving geometric problems using mediated mathematical discourse (for teachers and pupils). Procedia - Social and Behavioral Sciences, 209, 519-525. https:// doi.org/10.1016/j.sbspro.2015.11.282

Kurvinen, E., Kaila, E., Kajasilta, H., \& Laakso, M. (2019). Teachers' perceptions of digital learning path in mathematics, languages and programming. In 2019 42nd International Convention on Information and Communication Technology, Electronics 
and Microelectronics (MIPRO) (pp. 643-648). Opatija, Croatia.

Li, Y., Wang, K., Xiao, Y., Froyd, J. E., \& Nite, S. B. (2020). Research and trends in STEM education: A systematic analysis of publicly funded projects. International Journal of STEM Education, 7(1). https://doi.org/10.1186/ s40594-020-00213-8

Luo, L., Zhang, H., Tao, Y., Yang, X., Yan, B., \& Wang, Y. (2018, March 5-9). A study on characteristics of TPACK structure for MOOC teachers. In Proceedings - 6th International Conference of Educational Innovation Through Technology, EITT 2017. https://doi.org/10.1109/EITT.2017.10

Marshall, N., Buteau, C., Jarvis, D. H., \& Lavicza, Z. (2012). Do mathematicians integrate computer algebra systems in university teaching? Comparing a literature review to an international survey study. Computers and Education, 58(1), 423-434. https://doi.org/10.1016/j.compedu.2011.08.020

McCulloch, A. W., Hollebrands, K., Lee, H., Harrison, T., \& Mutlu, A. (2018). Factors that influence secondary mathematics teachers' integration of technology in mathematics lessons. Computers and Education, 123(April), 26-40. https://doi.org/10.1016/j.compedu.2018.04.008

Mishra, P., Koehler, M. J., \& Henriksen, D. (2011). The seven trans-disciplinary habits of mind: Extending the TPACK framework towards 21st century learning. Educational Technology, 11(2), 22-28. http:/ / punya.educ.msu.edu/publications/mishra-koehler-henriksen2011.pdf

Misrom, N. S., Abdurrahman, M. S., Abdullah, A. H., Osman, S., Hamzah, M. H., \& Fauzan, A. (2020). Enhancing students' higher-order thinking skills (HOTS) through an inductive reasoning strategy using GeoGebra. International Journal of Eme, 15(3), 156-179.

Mudaly, V., \& Fletcher, T. (2019). The effectiveness of GeoGebra when teaching linear functions using the IPad. Problems of Education in the 21st Century, 77(1), 55-81. https://doi.org/10.33225/PEC/19.77.55

Ogbonnaya, U. I., \& Mushipe, M. (2020). The efficacy of GeoGebra-assisted instruction on students' drawing and interpretations of linear functions. International Journal of Learning, Teaching and Educational Research, 19(9), 1-14. https://doi.org/10.26803/ijlter.19.9.1

Özgün-Koca, S. A. (2010). Prospective teachers' views on the use of calculators with computer algebra system in algebra instruction. Journal of Mathematics Teacher Education, 13(1), 49-71. https://doi.org/10.1007/s10857-009-9126-z

Pfeiffer, C. (2017). A study of the development of mathematical knowledge in a GeoGebrafocused learning environment [Doctoral dissertation]. University of Stellenbosch. https://scholar.sun.ac.za

Piper, R. J. (2013). How to write a systematic literature review: A guide for medical $\begin{array}{llll}\text { students. National } & \text { AMR, } & 1(2), & 1-8 .\end{array}$ http://cures.cardiff.ac.uk/files/2014/10/NSAMR-Systematic-

Review.pdf\%0Acures.cardiff.ac.uk/files/2014/.../NSAMR-SystematicReview.pdf

Radu, I., McCarthy, B., \& Kao, Y. (2016). Discovering educational augmented reality math applications by prototyping with elementary-school teachers. In Proceedings of the IEEE Virtual Reality, 2016-July, 271-272. https://doi.org/10.1109/VR.2016.7504758

Saralar, I., Işiksal-Bostan, M., \& Akyüz, D. (2018). The evaluation of a pre-service mathematics teacher's TPACK: A case of 3D shapes with GeoGebra. International Journal for Technology in Mathematics Education, 25(2), 3-21. https://doi.org/10.1564/tme_v25.2.01

Takači, D., Stankov, G., \& Milanovic, I. (2015). Efficiency of learning environment using 
GeoGebra when calculus contents are learned in collaborative groups. Computers and Education, 82, 421-431. https://doi.org/10.1016/j.compedu.2014.12.002

Usman, M. (2019). Concept mapping instructional strategy and senior secondary students' performances and interest in algebra in Bauchi State. Abacus (Mathematics Education Series), 44(1), 236-243.

Warner, S., \& Kaur, A. (2017). The perceptions of teachers and students on a 21st century mathematics instructional model. International Electronic Journal of Mathematics Education, 12(2), 193-215.

Yong, S. T., Gates, P., Chan, A., Lee, C. S., Matthews, R., \& Tiong, K. M. (2019). Exploring the feasibility of computer games in mathematics education. In Proceedings of the HAVE 2019 - IEEE International Symposium on Haptic, Audio-Visual Environments and Games (pp. 1-6). Subang Jaya, Malaysia. https://doi.org/10.1109/HAVE.2019.8921018

Young, J. (2017). Technology-enhanced mathematics instruction: A second-order metaanalysis of 30 years of research. Educational Research Review, 22, 19-33. https:// doi.org/10.1016/j.edurev.2017.07.001

Za'ba, N., Ismail, Z., Abdullah, A. H., Za'ba, N., Ismail, Z., \& Abdullah, A. H. (2020). Preparing student teachers to teach mathematics with GeoGebra. Universal Journal of Educational Research, 8(5A), 29-33. https://doi.org/10.13189/ujer.2020.081904

Zualkernan, I. A. (2015). Gender differences in a technology-based numeracy intervention in a developing country. In Proceedings of the 2015 IEEE Global Humanitarian Technology Conference (GHTC) (pp. 414-419). Seattle, WA, USA. https://ieeexplore.ieee.org/stamp/stamp.jsp?tp=\&arnumber $=7344005$ 